\title{
POZIOM NASILENIA LĘKU U PACJENTÓW LECZONYCH CHIRURGICZNIE
}

\section{THE LEVEL OF ANXIETY IN PATIENTS TREATED SURGICALLY}

\author{
Renata Robaszkiewicz-Bouakaz ${ }^{1, a}$, Ewelina Smektała², Dorota Branecka-Woźniak ${ }^{3, b}$, \\ Sylwia Wieder-Huszla ${ }^{1, c}$, Joanna Owsianowska ${ }^{1, d}$, Anna Jurczak ${ }^{1, e}$ \\ ${ }^{1}$ Zakład Pielęgniarstwa Specjalistycznego, Wydział Nauk o Zdrowiu, Pomorski Uniwersytet Medyczny w Szczecinie \\ ${ }^{2}$ Studenckie Koło Naukowe, Zakład Pielęgniarstwa Specjalistycznego, Wydział Nauk o Zdrowiu, Pomorski Uniwersytet Medyczny w Szczecinie \\ ${ }^{3}$ Katedra i Zakład Ginekologii i Zdrowia Prokreacyjnego, Wydział Nauk o Zdrowiu, Pomorski Uniwersytet Medyczny w Szczecinie
}

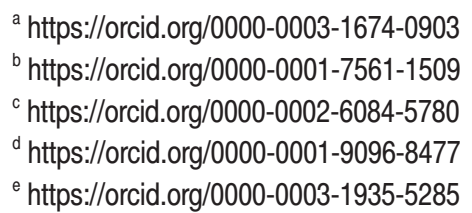

DOI: https://doi.org/10.20883/pielpol.2019.35

\section{STRESZCZENIE}

Wstęp. Hospitalizacja i leczenie chirurgiczne wiąże się z uczuciem lęku, którego doświadcza pacjent znajdujący się w nowej sytuacji, na które składa się obawa o własne zdrowie i życie.

Cel. Celem była analiza nasilenia lęku oraz jego determinanty u pacjentów hospitalizowanych w oddziale chirurgicznym.

Materiał i metody. Badania przeprowadzono w Samodzielnym Publicznym Zakładzie Opieki Zdrowotnej MSWiA w Szczecinie. Badaniem objęto 170 hospitalizowanych w Oddziale Chirurgii Ogólnej. Zastosowano metodę sondażu diagnostycznego z użyciem autorskiego kwestionariusza ankiety oraz Inwentarz Stanu i Cechy Lęku (STAI) służącego do pomiaru natężenia lęku jako stanu oraz jako cechy.

Wyniki. W badanej grupie kobiety stanowiły $48,2 \%$, a mężczyźni $52,8 \%$. Średnia wieku wynosiła 51,5 lat. Wiek oraz wykształcenie miały wpływ na lęk jako cechę. Grupa kobiet oczekujących na zabieg hemikolektomii miała wyższy poziom lęku jako stanu i jako cechy. Mieszkańcy mniejszych miast charakteryzowali się wyższym poziomem lęku jako cechy. Osoby z brakiem wsparcia miały wyższy poziom lęku, zarówno jako stanu oraz jako cechy. Wykazano, że wyższy wynik na skali jednego lęku związany był z wyższym wynikiem na skali drugiego lęku.

Wnioski. 1) W badanej grupie pacjentów chirurgicznych determinantami nasilającymi lęk jako stan były: płeć, brak wsparcia ze strony rodziny oraz przyczyna hospitalizacji. 2) Wzrost lęku jako cechy intensyfikuje wiek, płeć, wykształcenie, miejsce zamieszkania, poziom wsparcia oraz przyczyna hospitalizacji.

SŁOWA KLUCZOWE: hospitalizacja, lęk okołooperacyjny, natężenie lęku.

\begin{abstract}
Introduction. Hospitalization and surgical treatment is often associated with the feeling of fear experienced by the patient who is in a new situation, which also includes concern for their own health and life causes.

Aim. The aim of the study was to analyze the severity of anxiety and its determinants in patients hospitalized in the surgical ward. Material and methods: The research was carried out at the Independent Public Health Care Center of the Ministry of Interior and Administration in Szczecin. The study included 170 patients hospitalized at the Department of General Surgery.

Material and methods. The method of a diagnostic survey using an author's questionnaire and a State-Trait Anxiety Inventory (STAl) tool for measuring the intensity of anxiety as a condition and as a trait.

Results. The surveyed group included women, $48.2 \%$ and men, $52.8 \%$. The average age was 51.5 years. The age and education had an effect on anxiety as a trait. Studies revealed that a group of women waiting for hemicolectomy had a higher level of anxiety as a condition and as a trait. Inhabitants of smaller cities were characterized by a higher level of anxiety as a characteristic of people living in large cities over 100,000 residents. People with no support had a higher level of anxiety, both as a state and as traits. It was shown that the higher score on the scale of one anxiety was associated with a higher score on the second anxiety scale.

Conclusions. 1) In the examined group of surgical patients, it was shown that the determinants increasing anxiety as a state were: gender, lack of support from the family, reason of hospitalization. 2) The increase in anxiety as a trait is intensified by age, sex, education, place of residence, reason of hospitalization.
\end{abstract}

KEYWORDS: hospitalization, perioperative anxiety, intensity of anxiety. 


\section{Wprowadzenie}

Hospitalizacja wiąże się z uczuciem lęku, którego doświadcza pacjent znajdujący się w nowej sytuacji, na które składa się obawa o własne życie i zdrowie. W leczeniu długotrwałego lęku niezbędna jest pomoc psychologiczna i psychoterapia, gdyż tego typu emocje mogą spowodować wycofanie jednostki ze społeczeństwa oraz doprowadzić do sytuacji, w której występował będzie „lęk przed lękiem” [1].

Odczuwanie lęku nierozłącznie związane jest ze stresem. W odpowiedzi organizmu na sytuacje stresowe zachodzi uogólniona reakcja części współczulnej układu autonomicznego. Wzrost stężenia adrenaliny, noradrenaliny i kortyzolu występuje w wyniku reakcji organizmu na niepewność, natomiast w reakcji na złość następuje jedynie wzrost noradrenaliny oraz kortyzolu. Reakcja ta określana jest jako dodatnie sprzężenie zwrotne [2].

Codzienność oraz znajomość otoczenia pomimo różnorodności składa się na pewną stałość. Dzięki tej stabilności możliwe jest przewidywanie bardziej lub mniej prawdopodobnej przyszłości oraz właściwe przygotowanie się do niej. Niespodziewana zmienność powoduje wyzwolenie uczucia lęku. Jeśli nowa sytuacja w życiu codziennym pacjenta nie jest standardowa, to pojawia się krótko trwające doznanie niepokoju oraz wyładowanie wegetatywne [3].

Leczenie chirurgiczne powoduje obciążenie emocjonalne, które każdy pacjent przeżywa w sposób indywidualny. Bromboszcz [4] dokonał podziału lęku podczas hospitalizacji, w której wyodrębnił trzy jego fazy pojawiające się w okresie okołooperacyjnym. Pierwsza faza jest to czas od przyjęcia do szpitala do czasu podjęcia decyzji o zabiegu operacyjnym. Na drugą fazę składa się znieczulenie oraz operacja, zaś trzecia to okres po operacji. Do przyczyn stanu niepokoju zalicza się: strach przed tym, co nadejdzie, strach przed dolegliwościami związanymi z zabiegiem operacyjnym i przed zagrożeniem życia.

Często spotykaną reakcją wywołaną lękiem jest wrogie nastawienie do otaczającego świata, depresja oraz złość. Do czynników wzmagających uczucie lęku zaliczono: płeć żeńską, chorobę psychiczną, palenie wyrobów tytoniowych oraz chorobę nowotworową [5].

\section{Cel pracy}

Celem pracy była analiza nasilenia lęku oraz jego determinantów u pacjentów hospitalizowanych w oddziale chirurgicznym.

\section{Materiał}

Grupę badaną stanowiło 170 pacjentów (kobiety 48,2\%, mężczyźni - 52,8\%) hospitalizowanych w Od- dziale Chirurgii Ogólnej w Samodzielnym Publicznym Zakładzie Opieki Zdrowotnej MSWiA w Szczecinie.

\section{Metody}

Badania przeprowadzono metodą sondażu diagnostycznego w okresie od września do listopada 2016 roku. W badaniach wykorzystano polską adaptację standaryzowanego kwestionariusza Inwentarza Stanu i Cechy Lęku STAI (State-Trait Anxiety Inventory), opracowaną przez Spielberga [6]. Kwestionariusz złożony jest $z$ dwóch podskal z których jedna X-1 służy do pomiaru lęku jako stanu, a druga X-2 lęku jako cechy. Kwestionariusz STAI daje dwa osobne wyniki dla X-1 i X-2, które mieszczą się w przedziale między 20-80 punktów, przy czym 20 punktów określa niskie nasilenie lęku, a 80 punktów oznacza lęk wysoki. Do oceny sytuacji socjodemograficznej i zdrowotnej wykorzystano autorski kwestionariusz ankiety składający się z 12 pytań. Zawierał on pytania dotyczące wieku, płci, miejsca zamieszkania, wykształcenia, sytuacji zawodowej, sytuacji materialnej, wsparcia emocjonalnego ze strony rodziny oraz rodzaju wykonywanego zabiegu. Analizę statystyczną zebranego materiału wykonano w programie SPSS. Różnice pomiędzy 2 grupami wykonano parametrycznym testem t-Studenta dla prób niezależnych. Analizę wariancji wykonano za pomocą testu post-hoc (test Dunna). Dla dwóch lub więcej grup wykonano nieparametryczny test ANOVA KruskalaWallisa. W analizach za istotne przyjęto efekty, dla których wartość prawdopodobieństwa p była mniejsza od przyjętego poziomu istotności 0,05.

\section{Wyniki}

Największy odsetek $(56,4 \%)$ badanych stanowiły osoby zamieszkujące duże aglomeracje miejskie liczące ponad 100 tys. mieszkańców. W miastach liczących 10100 tys. mieszkańców zamieszkiwało 17,7\% badanych, a na wsi 15,4\%. Najmniej liczną grupe (10,5\%) stanowili ankietowani, którzy deklarowali jako miejsce stałego pobytu miasta liczące 10 tys. i mniej mieszkańców.

W badanej grupie średnia wieku wynosiła 51,5 lat. Analiza statystyczna wykazała, że wiek nie miał wpływu na lęk jako stan, jednak model wpływu wieku na lęk jako cecha był istotny statystycznie (Rycina 1).

Najwyższy średni wynik $(64,5 \pm 5,88)$ w zakresie lęku jako stanu uzyskali pacjenci poddani hemicolektomii, natomiast najniższy średni wynik w tym samym zakresie $(40,52 \pm 12,66)$ uzyskali chorzy, którzy poddani badaniom diagnostycznym. W zakresie lęku jako cechy najwyższy średni wynik $(48,6 \pm 7,64)$ uzyskali pacjenci poddani operacjom na kończynie górnej, natomiast najniższy średni wynik w tym samym zakresie $(38,19 \pm$ $9,11)$ uzyskali chorzy, którzy byli poddani badaniom dia- 
gnostycznym. Analiza wykazała istotne statystycznie zależności pomiędzy przyczyna hospitalizacji a lękiem jako stanem i cechą $(p<0,05)$ (Tabela 1).

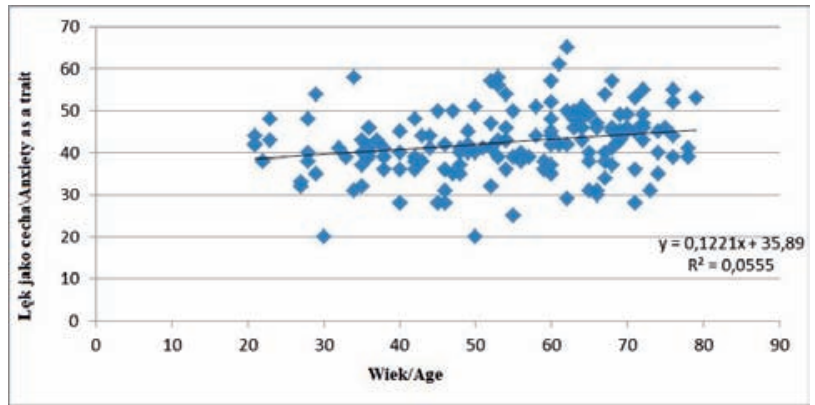

Rycina 1. Analiza lęku jako cechy z uwzględnieniem wieku badanych Figure 1. Analysis of anxiety as a trait with regard to age

Źródło: opracowanie własne

Source: author's own analysis

Tabela 1. Analiza lęku jako stanu i cechy z uwzględnieniem przyczyny hospitalizacji

Table 1. Analysis of anxiety as a state and as a trait including the reasons for hospitalization

\begin{tabular}{|c|c|c|c|c|c|c|c|}
\hline & $\begin{array}{l}\text { Przyczyna } \\
\text { hospitalizacji/ } \\
\text { Reasons for } \\
\text { hospitalization }\end{array}$ & $\mathrm{N}$ & $\mathrm{M} \pm \mathrm{SD}$ & Min-Max & Q1-Q3 & $\mathrm{Me}$ & $p^{*}$ \\
\hline \multirow{10}{*}{$\begin{array}{l}\text { Lęk } \\
\text { jako } \\
\text { stan/ } \\
\text { Anxiety } \\
\text { as } \\
\text { a state }\end{array}$} & $\begin{array}{l}\text { Usunięcie żylaków } \\
\text { kończyny dolnej/ } \\
\text { Removal of varicose } \\
\text { veins of the lower } \\
\text { limb }\end{array}$ & 29 & $43,48 \pm 9,33$ & $28-65$ & $38-52,5$ & 40 & \\
\hline & $\begin{array}{l}\text { Usunięcie żylaków } \\
\text { odbytu/ } \\
\text { Removal of hemor- } \\
\text { rhoids }\end{array}$ & 11 & $43,36 \pm 8,56$ & $30-57$ & $37-47$ & 44 & \\
\hline & $\begin{array}{l}\text { Plastyka przepukliny } \\
\text { Hernia plastic } \\
\text { surgery }\end{array}$ & 20 & $42,75 \pm 7,45$ & $33-57$ & $35,25-50,25$ & 42 & \\
\hline & $\begin{array}{l}\text { Zabieg naczyniowy/ } \\
\text { Vascular surgery }\end{array}$ & 7 & $43,43 \pm 6,88$ & $33-52$ & $36-50$ & 44 & \\
\hline & $\begin{array}{l}\text { Cholecystektomia/ } \\
\text { Cholecystectomy }\end{array}$ & 15 & $45,73 \pm 10,75$ & $32-62$ & $35-59$ & 42 & 0,001 \\
\hline & $\begin{array}{l}\text { Diagnostyka/ } \\
\text { Diagnostics }\end{array}$ & 31 & $40,52 \pm 12,66$ & $20-67$ & $29-49$ & 42 & \\
\hline & $\begin{array}{l}\text { Operacja tarczycy/ } \\
\text { Thyroid surgery }\end{array}$ & 14 & $44,57 \pm 8,05$ & $33-61$ & $38-52,25$ & 41,5 & \\
\hline & $\begin{array}{l}\text { Zabieg endosko- } \\
\text { powy/ } \\
\text { Endoscopic surgery }\end{array}$ & 32 & $47,53 \pm 11,75$ & $27-68$ & $37-58,75$ & 47 & \\
\hline & $\begin{array}{l}\text { Operacja kończyny } \\
\text { górnej/ } \\
\text { Upper limb surgery }\end{array}$ & 5 & $48 \pm 13,11$ & $27-62$ & $37-58,5$ & 49 & \\
\hline & $\begin{array}{l}\text { Hemikolektomia/ } \\
\text { Hemicolectomy }\end{array}$ & 6 & $64,5 \pm 5,88$ & $57-72$ & $58,5-68,25$ & 66 & \\
\hline
\end{tabular}

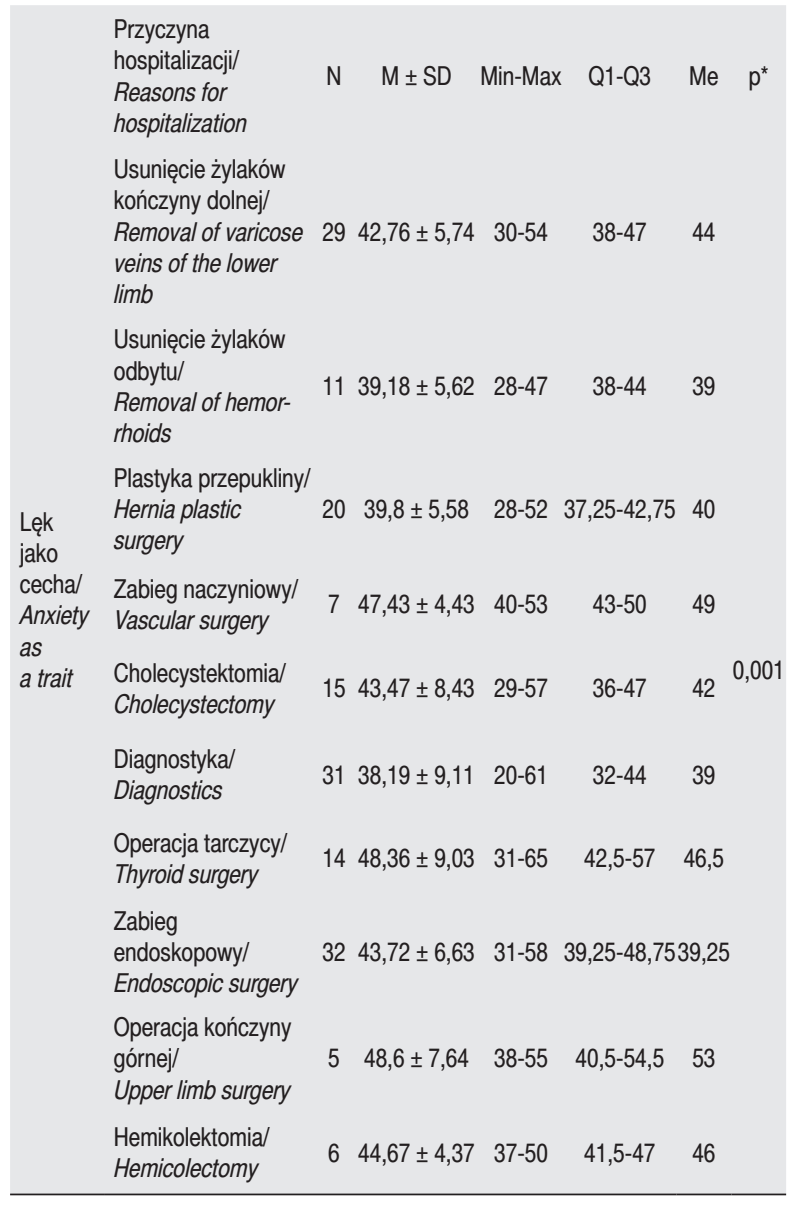

*test Kruskala-Wallisa + analiza post-hoc (test Dunna); M - średnia; SD - odchylenie standardowe; Min - minimum; Max - maksimum; Me - mediana; p - poziom istotności; Q1 - kwartyl pierwszy; Q3 - kwartyl trzeci

*Kruskal-Wallis test + post-hoc analysis (Dunn's test); M - mean; SD - standard deviation; Min - minimum; Max - maximum; Me - median; $p$ - level of significance; Q1- first quartile; Q3 - third quartile

Źródło: opracowanie własne

Source: author's own analysis

Najwyższą średnią lęku jako stanu otrzymały osoby z wykształceniem zasadniczym zawodowym (48,23 \pm 10,44), a najniższą osoby z wykształceniem wyższym licencjackim/inżynierskim $(38,06 \pm 9,45)$. Z kolei najwyższą średnią lęku jako cechy uzyskały osoby z wykształceniem podstawowym $(48,5 \pm 7,17)$, a najniższą osoby, które ukończyły studia trzeciego stopnia $(35,5 \pm 6,36)$. Przeprowadzona analiza wykazała istotną statystycznie zależność pomiędzy lękiem, jako cechą a wykształceniem badanych $(p<0,05)$ (Tabela 2).

Spośród 170 badanych, aż 88,82\% ( $n=151)$ deklarowała, że posiada wsparcie w rodzinie. U pacjentów nie mających wsparcia ze strony najbliższych lęk jako stan i cecha osiągał wyższe średnie wartości odpowiednio $(49,89 \pm 10,01)$ i $(46,11 \pm 5,79)$ (Tabela 3$)$. 
U kobiet zaobserwowano wyższy poziom lęku jako cechy $(42,02 \pm 7,66)$ i lęku jako stanu $(47,11 \pm 11,13)$. W obu przypadkach był to lęk o średnim nasileniu. Analiza wykazała istotną statystycznie zależność pomiędzy płcią żeńską i męską ( $p<0,05)$ (Tabela 4).

Tabela 2. Analiza lęku jako stanu i cechy z uwzględnieniem wykształcenia badanych

Table 2. Analysis of anxiety as a state and as a trait with regard to education

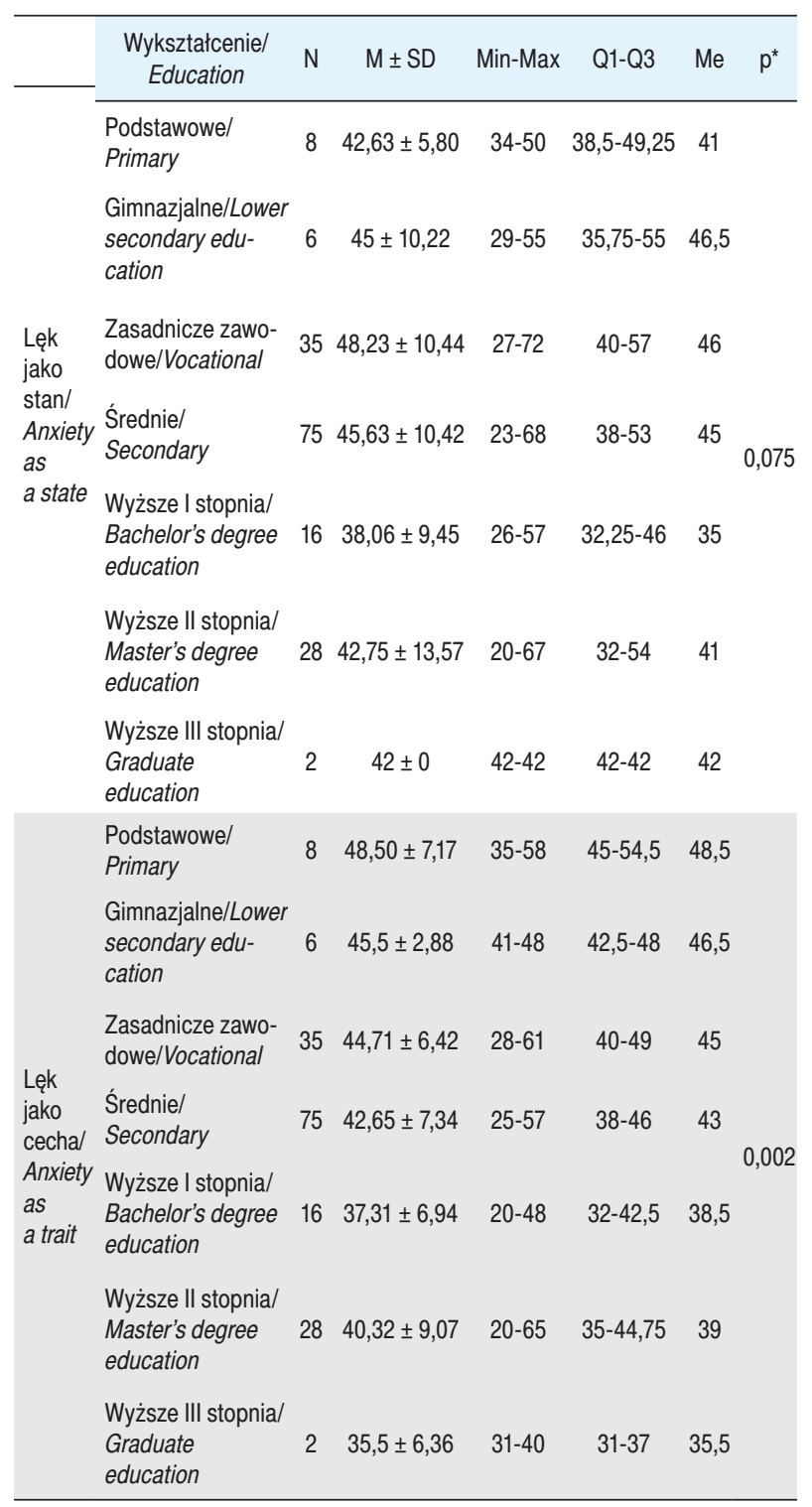

*test Kruskala-Wallisa + analiza post-hoc (test Dunna); M - średnia; SD - odchylenie standardowe; Min - minimum; Max - maksimum; Me - mediana; p - poziom istotności; Q1 - kwartyl pierwszy; Q3 - kwartyl trzeci

"Kruskal-Wallis test + post-hoc analysis (Dunn's test); M - mean; $S D$ - standard deviation; Min - minimum; Max - maximum; Me - median; $p$ - level of significance; Q1 - first quartile; Q3 - third quartile

Źródło: opracowanie własne

Source: author's own analysis
Tabela 3. Analiza lęku jako cechy i stanu z uwzględnieniem wsparcia ze strony rodziny

Table 3. Analysis of anxiety as a state and as a trait with regard to support from the family

\begin{tabular}{|c|c|c|c|c|c|c|c|}
\hline \multicolumn{2}{|c|}{$\begin{array}{c}\text { Wsparcie ze strony } \\
\text { rodziny/ } \\
\text { Support from } \\
\text { the family } \\
\end{array}$} & $\mathrm{N}$ & $\mathrm{M} \pm \mathrm{SD}$ & Min-Max & Q1-Q3 & $\mathrm{Me}$ & $p^{*}$ \\
\hline $\begin{array}{l}\text { Lęk } \\
\text { jako }\end{array}$ & Tak/Yes & 151 & $44,05 \pm 10,87$ & $20,00-67,00$ & 43,00 & $36,00-53,00$ & \\
\hline $\begin{array}{l}\text { stan/ } \\
\text { Anxiety } \\
\text { as a state }\end{array}$ & Nie/No & 19 & $49,89 \pm 10,01$ & $20,00-65,00$ & 41,00 & $38,00-46,00$ & 0,03 \\
\hline $\begin{array}{l}\text { Lęk } \\
\text { jako } \\
\text { cecha/ }\end{array}$ & Tak/Yes & 151 & $41,98 \pm 7,74$ & $33,00-72,00$ & 49,00 & $42,00-55,50$ & 0,03 \\
\hline $\begin{array}{l}\text { Anxiety } \\
\text { as a trait }\end{array}$ & Nie/No & 19 & $46,11 \pm 5,79$ & $36,00-56,00$ & 47,00 & $42,00-50,25$ & \\
\hline
\end{tabular}

*test Kruskala-Wallisa + analiza post-hoc (test Dunna); M - średnia; SD - odchylenie standardowe; Min - minimum; Max - maksimum; Me - mediana; p - poziom istotności; Q1 - kwartyl pierwszy; Q3 - kwartyl trzeci

${ }^{*}$ Kruskal-Wallis test + post-hoc analysis (Dunn's test); $M$ - mean; SD - standard deviation; Min - minimum; Max - maximum; Me - median; p-level of significance; Q1-first quartile; Q3 - third quartile

Źródło: opracowanie własne

Source: the author's research

Tabela 4. Analiza lęku jako cechy i stanu z uwzględnieniem płci Table 4. Analysis of anxiety as a state and as a trait with regard to sex

\begin{tabular}{|c|c|c|c|c|c|c|c|}
\hline & & $\mathrm{N}$ & $\mathrm{M} \pm \mathrm{SD}$ & Min-Max & Q1-Q3 & $\mathrm{Me}$ & $\mathrm{p}^{*}$ \\
\hline $\begin{array}{l}\text { Lęk } \\
\text { jako } \\
\text { stan/ } \\
\text { Anxiety }\end{array}$ & $\begin{array}{l}\text { Mężczyzna/ } \\
\text { Man }\end{array}$ & 88 & $42,59 \pm 10,38$ & $20,00-68,00$ & $34,25-49,75$ & 0,007 & $\begin{array}{l}42,00 \\
7\end{array}$ \\
\hline $\begin{array}{l}\text { as } \\
\text { a state }\end{array}$ & $\begin{array}{l}\text { Kobieta/ } \\
\text { Woman }\end{array}$ & 82 & $47,11 \pm 11,13$ & $20,00-72,00$ & $39,00-54,25$ & & 46,00 \\
\hline $\begin{array}{l}\text { Lęk } \\
\text { jako } \\
\text { cecha/ }\end{array}$ & $\begin{array}{l}\text { Mężczyzna/ } \\
\text { Man }\end{array}$ & 88 & $41,05 \pm 7,63$ & $20,00-61,00$ & $37,00-46,75$ & 0,011 & 41,00 \\
\hline $\begin{array}{l}\text { Anxiety } \\
\text { as a trait }\end{array}$ & $\begin{array}{l}\text { Kobieta/ } \\
\text { Woman }\end{array}$ & 82 & $42,02 \pm 7,66$ & $28,00-65,00$ & $39,75-49,00$ & & 43,50 \\
\hline
\end{tabular}

*test Kruskala-Wallisa + analiza post-hoc (test Dunna); M - średnia; SD - odchylenie standardowe; Min - minimum; Max - maksimum; Me - mediana; p - poziom istotności; Q1 - kwartyl pierwszy; Q3 - kwartyl trzeci

*Kruskal-Wallis test + post-hoc analysis (Dunn's test); $M$ - mean; $S D$ - standard deviation; Min - minimum; Max - maximum; Me - median; $p$ - level of significance; Q1 - first quartile; Q3 - third quartile

Źródło: opracowanie własne

Source: author's own analysis

Dokonana analiza lęku jako stanu i cechy wykazała istotną statystycznie zależność pomiędzy ich poziomami. Średnia lęku jako stanu była wyższa $(44,77 \pm 10,95)$, niż średnia lęku jako cechy $(42,48 \pm 7,67)(p<0,05)$ (Tabela 5). 
Tabela 5. Analiza lęku jako stanu i cechy

Table 5. Analysis of anxiety as a state and as a trait

\begin{tabular}{lccccc}
\hline & M \pm SD & Min-Max & Q1-Q3 & Me & $p^{*}$ \\
\hline $\begin{array}{l}\text { Lęk } \\
\text { jako }\end{array}$ & & & & & \\
stan/ & $44,77 \pm 10,95$ & $20,00-72,00$ & $37,00-53,00$ & 44,00 & \\
$\begin{array}{l}\text { Anxiety } \\
\text { as a state }\end{array}$ & & & & & \\
Lęk & & & & & 0,002 \\
jako & & & & & \\
cecha / & $42,48 \pm 7,67$ & $20,00-65,00$ & $38,00-47,00$ & 42,00 & \\
$\begin{array}{l}\text { Anxiety } \\
\text { as a trait }\end{array}$ & & & & & \\
\hline
\end{tabular}

*test Kruskala-Wallisa + analiza post-hoc (test Dunna); M - średnia; SD - odchylenie standardowe; Min - minimum; Max - maksimum; Me - mediana; p - poziom istotności; Q1 - kwartyl pierwszy; Q3 - kwartyl trzeci

*Kruskal-Wallis test + post-hoc analysis (Dunn's test); M - mean; $S D$ - standard deviation; Min - minimum; Max - maximum; Me - median; $p$ - level of significance; Q1 - first quartile; Q3 - third quartile

Źródło: opracowanie własne

Source: author's own analysis

\section{Dyskusja}

Hospitalizacja niejednokrotnie wiąże się z koniecznością rezygnacji pacjenta z pełnionych ról społecznych, rodzinnych oraz zawodowych. Pobyt w szpitalu każda jednostka odbiera indywidualnie, co implikuje różne stany emocjonalne. Większości pacjentów towarzyszy lęk o średnim nasileniu. Jednak jego poziom uzależniony jest od poczucia zagrożenia, które może stanowić np. zabieg operacyjny, konieczność poddania się badaniom [7]. Negatywne uczucie związane z lękiem mogą spowodować oporność na premedykację przedoperacyjną, wzmożenie odczuwania dolegliwości bólowych, wydłużenie gojenia ran oraz dłuższy okres rekonwalescencji [8]. Według zespołu Bączyk [9] częstość występowania lęku przedoperacyjnego występuje na poziomie 25-80\% i uzależniony jest od zastosowanych metod badawczych. W badaniach własnych u chorych hospitalizowanych w oddziale chirurgii lęk jako cecha korelowała z wiekiem, gdyż wraz z wiekiem obserwowano jego wzrost. Nie wykazano natomiast wpływu wieku na lęk jako stan. Podobne wyniki uzyskała Bączyk [9], gdyż osoby w średnim wieku posiadały wyższy poziom lęku jako cechy. Odwrotną sytuację natomiast wykazały badania przeprowadzone przez Pawlaka i wsp. [10], ponieważ wg autorów lęk jako stan ściśle oddziałuje na wiek. Badania przeprowadzone przez Łoza i wsp. [11] dowodzą, że młodsi pacjenci, poniżej 36 roku życia, charakteryzują się lękiem o niższym nasileniu w porównaniu do pacjentów starszych. Analiza wyników własnych badań wskazuje, że istnieje zależność między poziomem wykształcenia, a lękiem jako cechą u chorych hospitalizowanych w oddziale chirurgii. Osoby z wykształce- niem podstawowym i gimnazjalnym posiadały wyższy poziom lęku jako cechy od osób z wykształceniem wyższym I, II i III stopnia. W badaniach Pawlaka i wsp. [12] natężenie lęku w okresie okołooperacyjnym także koreluje z poziomem wykształcenia. Według badaczy niski poziom wykształcenia jest czynnikiem wzmagającym lęk [12]. Podobne wyniki uzyskał Cosentino i wsp. [13] u pacjentek w okresie okołooperacynym leczonych chirurgicznie z przyczyn ginekologicznych, ponieważ poziom lęku miał związek z ich poziomem wykształcenia. Im niższe wykształcenie deklarowały badane, tym poziom lęku był wyższy. Pacjenci posiadający większe umiejętności interpersonalne w łatwiejszy sposób komunikują się i okazują swoje emocje oraz werbalizują swoje potrzeby, co w konsekwencji powoduje, że w mniejszym stopniu są narażeni na zaburzenia depresyjne. Zespół Pignay-Demaria dowodzi, że niski poziom wykształcenia predysponuje do wystąpienia zaburzeń depresyjnych w okresie okołooperacyjnym [14]. Zatem wsparcie emocjonalne ze strony bliskich jest bardzo znaczące dla pacjenta. Na podstawie przeprowadzonych badań własnych udowodniono, że osoby nie posiadające wsparcia ze strony rodziny wykazywały wyższy poziom lęku jako stanu i cechy. Z kolei osoby posiadające to wsparcie posiadały niższy poziom lęku. Badania Micik i Borbasi pokazały, że wsparcie od rodziny zwiększa poczucie własnej wartości oraz powoduje wzbudzenie zaufania, co potwierdziły uzyskane wyniki, gdyż 90\% pacjentów wymagało wsparcia od bliskich w okresie okołooperacyjnym [15]. Badania własne wykazały, że kobiety charakteryzowały się wyższym poziomem lęku, jako stanu i cechy niż mężczyźni. Podobne wyniki uzyskała w swoich badaniach Bączyk i wsp. [9]. Na tej podstawie można wysnuć wniosek, że płeć żeńska charakteryzuje się wyższą tendencją do występowania lęku podczas hospitalizacji.

Lęk jako stan jest stanem emocjonalnym chwilowym i przemijającym, często reakcją na daną sytuację. Z kolei lęk jako cecha jest rozumiany jako utrzymująca się, trwała cecha osobowości. Często charakteryzuje się gotowością jednostki do reagowania w pewnych sytuacjach stanem lęku [16]. W badaniach własnych dokonano oceny lęku jako stanu i cechy. Wykazano istotne statystycznie różnice między poziomami lęków, gdyż w badanej grupie osoby posiadające wyższy poziom lęku, jako cechy, odznaczały się wyższym poziomem lęku jako stanu. Wynik taki świadczy o większej odporności psychicznej osób z niższym poziomem lęku. Badura-Brzozowa i wsp. [17] z przeprowadzonych badań wywnioskowali, że wysokie wartości lęku jako stanu u pacjentów leczonych chirurgicznie mogą wynikać z nowej sytuacji oraz rzeczywistości, z jaką muszą się zmagać, a także ze zmianą obrazu własnego ciała. 
Emocje każdego człowieka podczas hospitalizacji nie są jednoznaczne, nie posiadają jedynie negatywnych cech, ale też w sposób pozytywny stymulują organizm chorego. Zmienność czynników, które przyczyniają się do pojawienia się lęku oraz ich różnorodność może mieć związek z wiekiem, płcią oraz doświadczeniami życiowymi, dlatego lęk należy definiować indywidualnie na każdym etapie hospitalizacji.

\section{Wnioski}

1. W badanej grupie pacjentów chirurgicznych determinantami nasilającymi lęk jako stan były: płeć, brak wsparcia ze strony rodziny oraz przyczyna hospitalizacji.

2. Wzrost lęku jako cechy intensyfikuje wiek, płeć, wykształcenie, poziom wsparcia oraz przyczyna hospitalizacji.

\section{Piśmiennictwo}

1. Krzyżowski J. Stany lękowe. Warszawa: Medyk; 2005.

2. Salomon P. Psychologia w medycynie wspomogą współpracę z pacjentem i proces leczenia. Gdańsk: Gdańskie Wydawnictwo Psychologiczne; 2002.

3. Kępiński A. Rytm życia. Kraków: Wydawnictwo Literackie; 2001.

4. Romanik W, Kański A, Soluch P, Szymańska O. Kwestionariuszowy i deklaratywny poziom lęku chorych przed operacją. Anest Inten Terap 2009; 2: 94-99.

5. Ziębicka J, Gajdosz R. Wybrane aspekty lęku u chorych oczekujących na operację. Anest Inten Terap 2006; 1: 41-44.

6. Wrześniewski K, Sosnowski T. Inwentarz Stanu i Cechy Lęku STAI. Polska adaptacja STAI. Pracownia Testów Psychologicznych, Warszawa Polskiego Towarzystwa Psychologicznego; 1996

7. Motyka M. Obawy pacjentów przygotowywanych do zabiegu operacyjnego. Sztuka leczenia 2001; 4: 23-6.

8. Ziętek P, Ziętek J, Szczypiór K. Lęk u chorych poddawanych alloplastyce stawów kolanowych w trybie skróconej hospitalizacji w świetle współczesnego piśmiennictwa. Psychiatr. Pol. 2014; 48(5): 1015-1024.

9. Bączyk B, Talarska D, Szubert J. Przyczyny lęku przedoperacyjnego u chorych leczonych chirurgicznie. Promocja zdrowia w chorobie i niepełnosprawności. Ann. UMCS Sect. D 2006; s. 152.
10. Pawlak A. Ocena wybranych objawów psychopatologicznych w okresie okołooperacyjnym u pacjentów poddawanych pomostowaniu aortalno-wieńcowemu. Kalety: Wydawnictwo Piotr Kalinowski 2012.

11. Łoza B, Opielak G, Szkodziak P, Bronikowska A, Bartyzel M. Lęk jako objaw łączący psychiatrię $z$ innymi dziedzinami medycyny somatycznej - poziom lęku u pacjentów wybranych działów somatycznych. Psychiatr. Prakt. Ogólnolek. 2004; 4(4): 193-195.

12. Pawlak A, Krejca M, Janas-Kozik M. Ocena leku i depresji w okresie okołooperacyjnym u pacjentów poddawanych rewaskularyzacji mięśnia sercowego. Psychiatr. Pol., 2012 tom XLVI;1: 70-71.

13. Cosentino M, Vidotto G, Ponchia R, Trovo S, Magistris M. Anxiety and acceptianse of gynecologial laparoscopie operations. Minerva Ginecol 2002; 54(20): 171-177.

14. Pignay-Demaria V, Lesperance F, Demaria RG, FrasureSmith N, Perrault LP. Depression and anxiety and outcomes of coronary artery bypass surgery. Ann. Thor. Surg. 2003;75: 314-321.

15. Micik S, Borbasi S. Effect of suport programme to reduce stress in spoudes partners' fall off' clinical pathways past cardiac surgery. August Crit Care 20002; 15 (1): 33-40.

16. Mielimąka M, Rutkowski K, Cyranka K, Sobański J, Dembińska $E$, Müldner-Nieckowski $Ł$. Lęk - cecha i lęk -stan u pacjentów leczonych intensywną, krótkoterminową psychoterapią grupową z powodu zaburzeń nerwicowych i osobowości. Psychiatr. Pol. ONLINE FIRST 2015 ; http:// dx.doi.org/10.12740/PP/OnlineFirst/60537.

17. Badura-Brzozowa K, Matysiakiewicz B, Piegza B. Ocena wpływu czynników socjogeograficznych na objawy lęku i depresji pacjentów po amputacju kończyny. Psychiatr. Pol. 2006; 2:335-345.

Artykuł przyjęty do redakcji: 09.10.2018.

Artykuł przyjęty do publikacji: 20.03.2019.

Źródło finansowania: Praca nie jest finansowana z żadnego źródła. Konflikt interesów: Autorzy deklarują brak konfliktu interesów.

\section{Adres do korespondencji:}

Renata Robaszkiewicz-Bouakaz

Zakład Pielęgniarstwa Specjalistycznego, Wydział Nauk o Zdrowiu, Pomorski Uniwersytet Medyczny w Szczecinie

ul. Żołnierska 48

71-210 Szczecin

tel.: 914800910

e-mail: reniq@poczta.onet.pl 